\title{
Recurrent Malignant Germ Cell Tumor
}

National Cancer Institute

\section{Source}

National Cancer Institute. Recurrent Malignant Germ Cell Tumor. NCI Thesaurus. Code C132853.

The reemergence of a malignant germ cell tumor after a period of remission. 